Девятова Т.А., Горбунова Н.С., Горбунова Ю.С., Гафар Х.Г. Распределение тяжелых металлов и бенз(а)пирена в нефтезагрязненных почвах города Кайяра (Ирак)

УДК 631.445.12

\title{
Распределение тяжелых металлов и бенз(а)пирена в нефтезагрязненных почвах города Кайяра (Ирак)
}

\author{
Девятова Т.А., Горбунова Н.С., Горбунова Ю.С., Гафар Х.Г. \\ Воронежский государственный университет
}

\begin{abstract}
Аннотация
Исследовано пространственное распределение нефтепродуктов и бенз(а)пирена в сероземах в результате аварийного разлива нефти в районе месторождения Кайяра (Ирак), а также валовое содержание и подвижные соединения тяжельх металлов - Pb, $\mathrm{Cd}, \mathrm{Cu}, \mathrm{Zn}, \mathrm{Mn}, \mathrm{Ni}$. Выявлено увеличение содержания нефтепродуктов и бенз(а)пирена в верхнем слое почв в зоне влияния нефтяного разлива. При попутном сжигании нефтяного газа происходит осаждение на поверхность почв исследуемых элементов. Содержание $\mathrm{Ni}$ значительно превышает фоновые концентращии. Превышение нормативов характерно и для подвижных соединений $C d$. В результате техногенной нагрузки, а также физикохимических особенностей исследуемых почв, изучаемые ТМ находятся в легкодоступном состоянии. Самый высокий процент подвижности характерен для Cd. Высокая подвижность элементов делает их активными с точки зрения миграции в сопряженные ландшафты. Важной особенностью региона является наличие пыльных бурь. Загрязненный нефтепродуктами и тяжельми металлами почвенный материал способен переносится на значительные расстояния, даже за небольшой промежуток времени. Тяжелье металль, бенз(а)пирен и нефтепродукты способны легко перемещаться не только в сопредельные среды, но и в организм человека.

Ключевые слова: СЕРОЗЕМЫ, ТЯЖЕЛЫЕ МЕТАЛЛЫ, СВИНЕЦ, КАДМИЙ, НИКЕЛЬ, ЦИНК, МЕДЬ, МАРГАНЕЦ, НЕФТЕПРОДУКТЫ, БЕНЗ(А)ПИРЕН

\section{Введение}

Поступление нефтепродуктов и нефти в окружающую среду, в том числе и в почвенный покров, является одной из самых важных экологических проблем [1-4]. Почва испытывает отрицательное воздействие от нефтяных разливов, а также
\end{abstract}


Девятова Т.А., Горбунова Н.С., Горбунова Ю.С., Гафар Х.Г. Распределение тяжелых металлов и бенз(а)пирена в нефтезагрязненных почвах города Кайяра (Ирак)

несанкционированного размещения нефтепродуктов и нефтесодержащих отходов. При нефтяном загрязнении почв происходит нарушение экологического равновесия почвенных экосистем, поэтому исследования по оценке состояния почв при разливах нефтепродуктов являются актуальными $[4,5]$. Помимо загрязнения почвенного покрова нефтепродуктами, происходит сопутствующее оседание на поверхности почв многих тяжелых металлов (ТМ), вследствие выбросов вредных веществ в атмосферу в результате сжигания попутного нефтяного газа (ПНГ) на факельных установках [6, 7].

Целью данной работы явилось исследование почвенного покрова на содержание в нем нефтепродуктов, бенз(а)пирена, валового содержания и подвижных соединений ТМ $\mathrm{Pb}, \mathrm{Cd}, \mathrm{Ni}, \mathrm{Cu}, \mathrm{Zn}, \mathrm{Mn}$, при различном расстоянии от нефтяного разлива и факельных установок месторождения Кайяра (Ирак).

\section{Объекты и методы}

Полевые работы по отбору почвенных образцов проводились вблизи города Кайяра (север Ирака, провинция Ниневия, расположенная на западном берегу р. Тигр), примерно в 60 км от города Мосула (рис. 1). Нефтеперерабатывающий завод Кайяра считается одним из самых известных и старейших нефтеперерабатывающих предприятий Ирака. Завод был открыт в 1956 году английскими нефтяными компаниями, с тех пор завод не модернизировался. Аварийные разливы нефти на территории прилегающей к заводу происходя постоянно (рис. 2). Сложившаяся ситуация несомненно вызывает загрязнение почвенного покрова и сопредельных сред. Отбор почвенных образцов проводился из 0-20 см слоя на расстоянии 1, 50, 100, 200, 500, 1000, 1500, 2000, 2500 и 3000 м от границы нефтяного разлива. В качестве фонового участка использовалась почва не подверженная загрязнению, находящаяся вдали от всех антропогенных источников загрязнений, в том числе и нефтяного.

В отобранных образцах было определенно содержание нефтепродуктов и бенз(а)пирена, а также валовое содержание и подвижные формы соединений $\mathrm{TM}-\mathrm{Pb}, \mathrm{Cd}$, $\mathrm{Ni}, \mathrm{Cu}, \mathrm{Zn}, \mathrm{Mn}$. Поскольку многие ТM, прежде всего $\mathrm{Pb}, \mathrm{Ni}, \mathrm{Mn}, \mathrm{Zn}$ являются обязательными составляющими при сжигании ПНГ на факельных установках, вокруг них формируются огромные ореолы загрязнения почв [8]. Лабораторные исследования 
Девятова Т.А., Горбунова Н.С., Горбунова Ю.С., Гафар Х.Г. Распределение тяжелых металлов и бенз(а)пирена в нефтезагрязненных почвах города Кайяра (Ирак)

проводились в федеральном государственном бюджетном учреждении «Центр лабораторного анализа и технических измерений по центральному федеральному округу» (филиал ЦЛАТИ по Воронежской области). Результаты были обработаны статистически с использованием пакета анализа программы Microsoft Excel 2010.

В результате климатических особенностей территории (чрезвычайно малого количества осадков, выпадающих за весенне-зимний период) сформировались средиземноморские (субтропические) пустыни [9]. Почвенный покров территории представлен сероземами, образовавшимися на карбонатных или известковых корах выветривания [10]. Исследуемая территория приурочена к автоморфным участкам, поэтому карбонаты не накапливаются на поверхности, новообразования уходят в более глубокие слои почв.

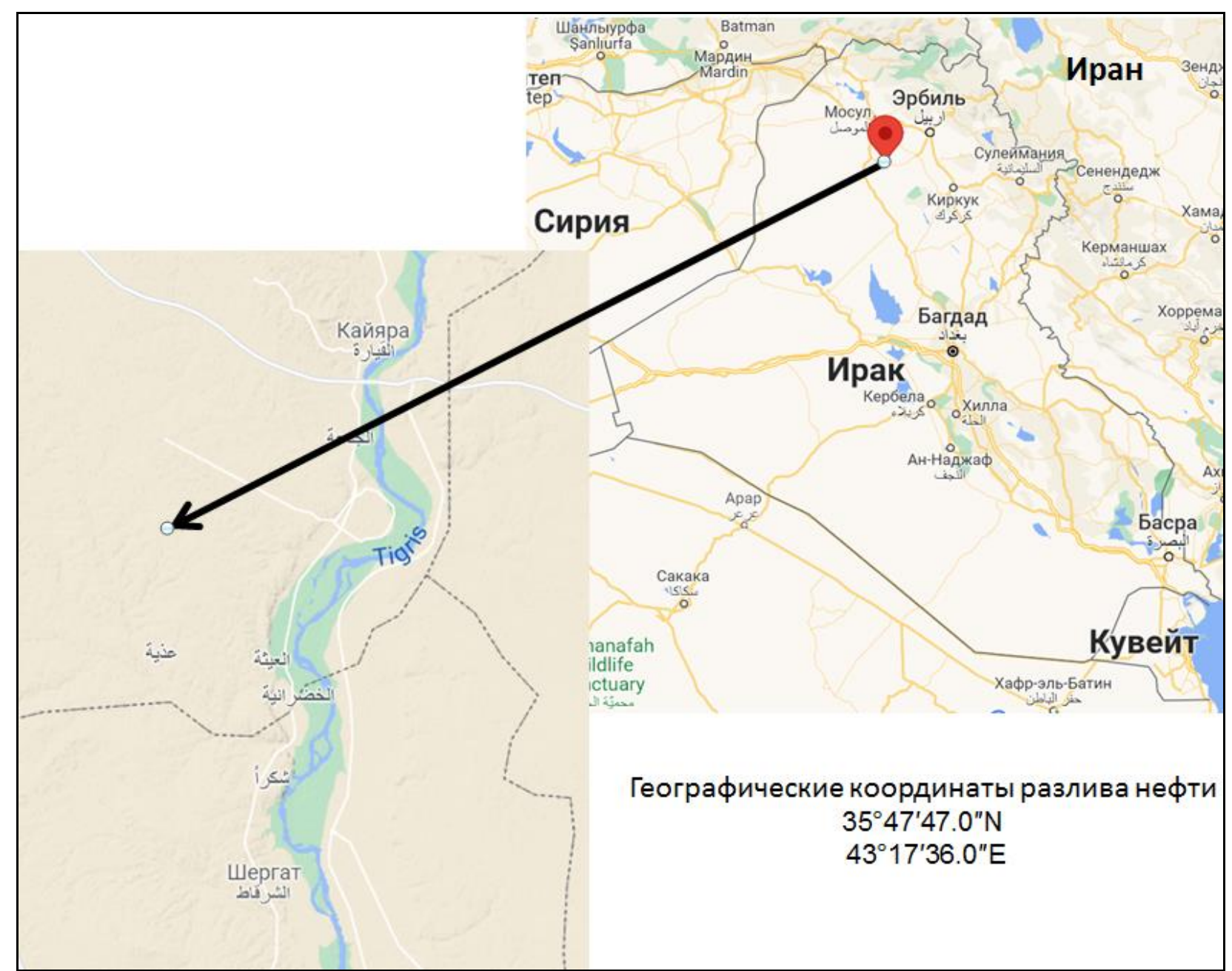

Рис. 1. Географические координаты и территория отбора почвенных образцов (Кайяра, Мосул) 
Девятова Т.А., Горбунова Н.С., Горбунова Ю.С., Гафар Х.Г. Распределение тяжелых металлов и бенз(а)пирена в нефтезагрязненных почвах города Кайяра (Ирак)

Электронный научно-производственный журнал «АггроЭкоИнфо»

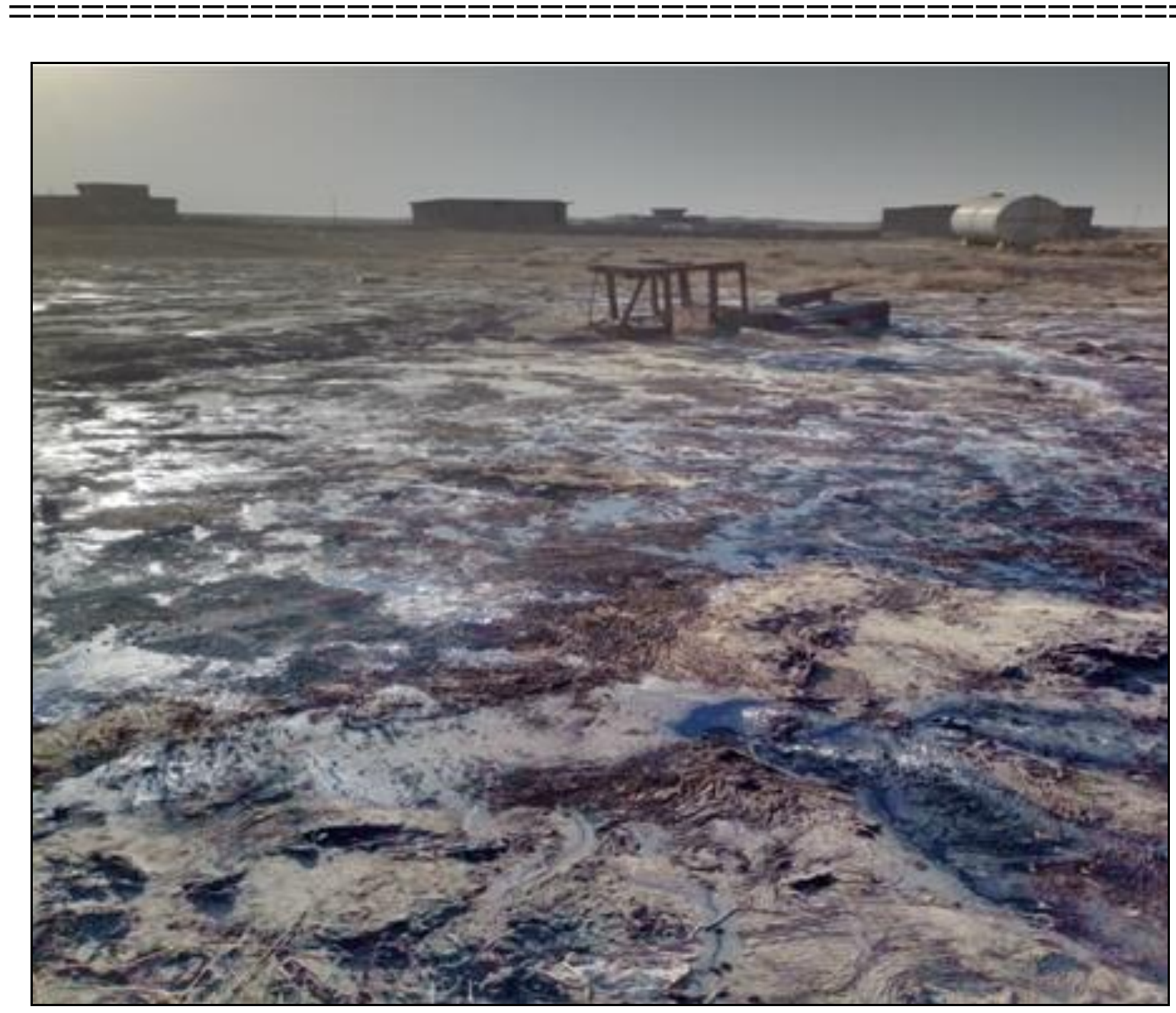

Рис. 2. Аварийный разлив нефти (Кайяра, Мосул)

Аридизация и опустынивание являются важными составляющими почвообразовательного процесса района исследования. Сухой климат с круглогодовым преобладанием величины испарения над количеством атмосферных осадкой (господство испарительного водного режима) является главным условием образования засоленных почв и, как следствие, очень скудного растительного покрова. При таких условиях наличие ветровой эрозии, переходящей в пыльные бури, имеет характер постоянного явлением. В результате происходит территориальное перераспределение почвенного мелкозема и исследуемых загрязнителей.

\section{Результаты исследований}

Исследуемые почвы засолены, степень засоления грунтовых вод часто достигает 80 г/л, а почв - 3\% и более [11]. Преобладает чисто хлоридное $\mathrm{Mg}, \mathrm{Ca}, \mathrm{Na}$ засоление. На 
Девятова Т.А., Горбунова Н.С., Горбунова Ю.С., Гафар Х.Г. Распределение тяжелых металлов и бенз(а)пирена в нефтезагрязненных почвах города Кайяра (Ирак)

Электронныи научно-производственньй жсурнал «АгроЭкоИнфо»

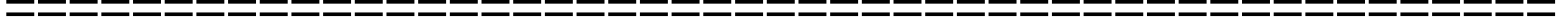

исследуемой территории соленакопление в почвенном покрове сопровождается наличием нефтяных залежей. Так называемая нефтяная залежь «плавает» на высокоминерализованных водах (до 200 г/л). Очень часто нефтяные воды через трещины и тектонические разломы выходят на поверхность (рис. 3), вызывая дополнительное специфическое засоление почв [9-11].

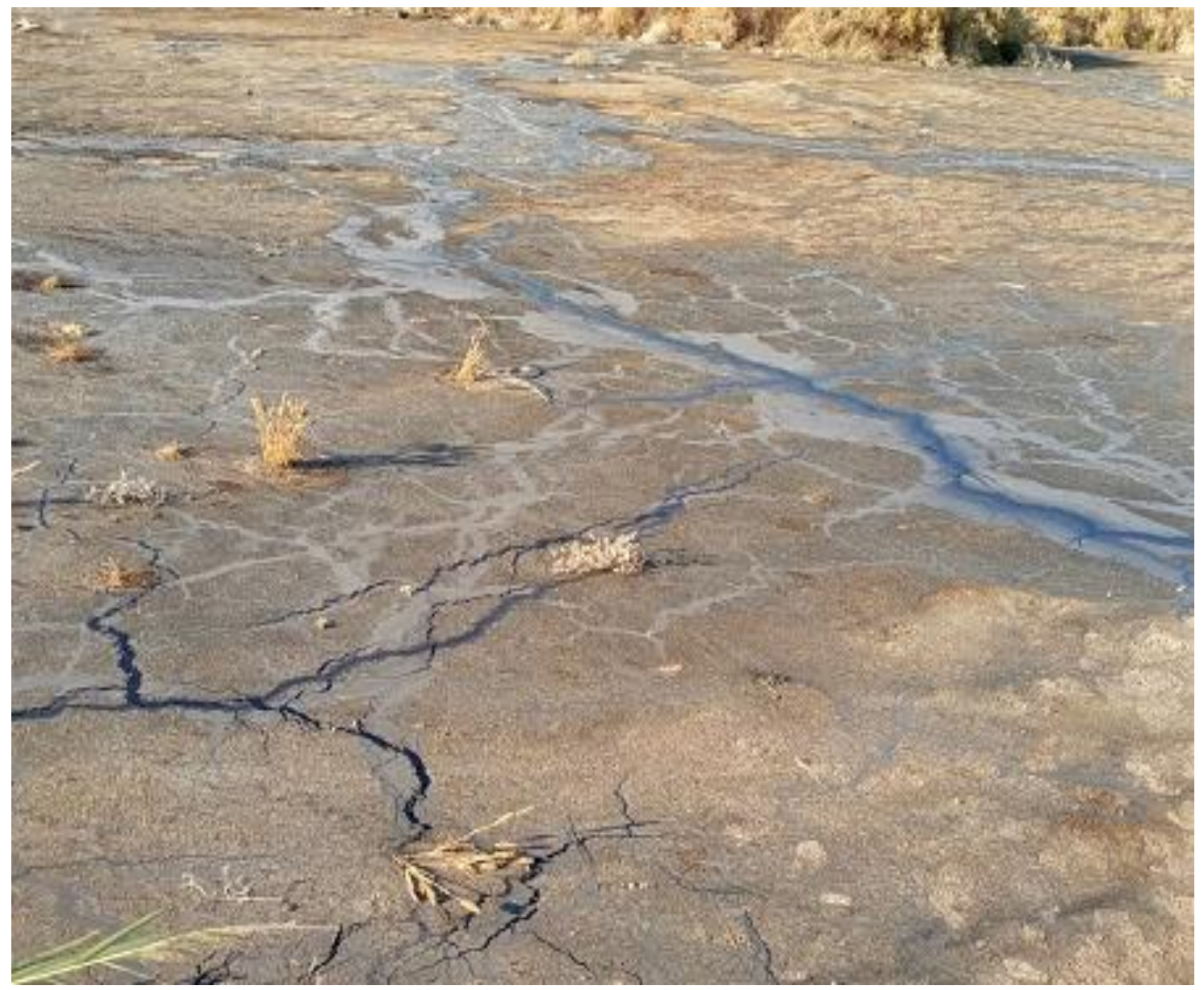

Рис. 3. Выход нефтяных вод на поверхность через тектонические трещины (Кайяра, Мосул)

Как следствие исследуемые сероземы имеют слабощелочную и щелочную реакцию почвенного раствора. Гранулометрический состав супесчаный. Содержание гумуса в них не превышает $1,5 \%$.

Изучаемые TM - Pb, Ni, Zn, Mn являются составляющими элементами, входящими в состав ПНГ на факельных установках. При избыточном содержании ТМ в почвенном покрове, они способны вовлекаться в большой геологический и малый биологический 
Девятова Т.А., Горбунова Н.С., Горбунова Ю.С., Гафар Х.Г. Распределение тяжелых металлов и бенз(а)пирена в нефтезагрязненных почвах города Кайяра (Ирак)

круговороты веществ. Вовлечение металлов в миграционные циклы зависит не только от их количественного содержания, их процента подвижности, но от физических и физикохимических свойств почв. Наибольшей канцерогенностью при избыточном содержании обладают $\mathrm{Pb}, \mathrm{Cd}, \mathrm{Ni}$ (табл. 1).

Таблица 1. Валовое содержание (числитель) и подвижные формы соединений (знаменатель) ТМ (мг/кг) в верхнем 0-20 см слое на различном расстоянии от источника нефтяного загрязнения, $\mathrm{n}=5$

\begin{tabular}{|c|c|c|c|c|c|c|}
\hline \multirow{2}{*}{$\begin{array}{c}\text { Расстояние } \\
\text { от источника } \\
\text { загрязнения, } \\
\text { м }\end{array}$} & \multicolumn{6}{|c|}{ Элемент, $\bar{x} \pm s_{\bar{x}}$} \\
\hline & $\mathrm{Pb}$ & $\mathrm{Cd}$ & $\mathrm{Ni}$ & $\mathrm{Zn}$ & $\mathrm{Mn}$ & $\mathrm{Cu}$ \\
\hline \multirow{2}{*}{1} & $\underline{5,3 \pm 0,16}$ & $\underline{0,79 \pm 0,02}$ & $145,5 \pm 4,37$ & $\underline{22,1 \pm 0,66}$ & $\underline{269,2 \pm 8,08}$ & $\underline{13,6 \pm 0,41}$ \\
\hline & $\overline{0,8 \pm 0,02}$ & $0,3 \pm 0,01$ & $77,2 \pm 2,32$ & $7,1 \pm 0,21$ & $152,5 \pm 4,58$ & $2,5 \pm 0,08$ \\
\hline \multirow{2}{*}{50} & $11,2 \pm 0,34$ & $\underline{0,28 \pm 0,08}$ & $141,3 \pm 4,24$ & $40,5 \pm 1,22$ & $361,5 \pm 10,8$ & $14,1 \pm 0,42$ \\
\hline & $\overline{0,8 \pm 0,02}$ & $\overline{0,21 \pm 0,01}$ & $92,3 \pm 2,77$ & $2,6 \pm 0,08$ & $\overline{226,9 \pm 6,81}$ & $2,1 \pm 0,06$ \\
\hline \multirow{2}{*}{100} & $14,5 \pm 0,44$ & $\underline{0,25 \pm 0,08}$ & $\underline{205,4 \pm 61,6}$ & $52,5 \pm 1,58$ & $\underline{322,5 \pm 9,68}$ & $\underline{30,3 \pm 0,91}$ \\
\hline & $\overline{2,0 \pm 0,06}$ & $\overline{0,18 \pm 0,01}$ & $\overline{86,7 \pm 2,60}$ & $8,2 \pm 0,25$ & $\overline{238,1 \pm 7,14}$ & $2,2 \pm 0,07$ \\
\hline \multirow{2}{*}{200} & $9,0 \pm 0,27$ & $\underline{0,18 \pm 0,05}$ & $\underline{198,6 \pm 5,96}$ & $\underline{38,6 \pm 1,16}$ & $295,7 \pm 7,79$ & $\underline{34,1 \pm 1,02}$ \\
\hline & $1,3 \pm 0,04$ & $\overline{0,15 \pm 0,01}$ & $93,4 \pm 2,80$ & $1,3 \pm 0,04$ & $209,4 \pm 6,28$ & $2,5 \pm 0,08$ \\
\hline \multirow{2}{*}{500} & $\underline{8,7 \pm 0,26}$ & $\underline{0,12 \pm 0,04}$ & $\underline{189,7 \pm 5,69}$ & $\underline{37,1 \pm 1,11}$ & $286,1 \pm 8,58$ & $\underline{18,5 \pm 0,56}$ \\
\hline & $\overline{1,4 \pm 0,04}$ & $\overline{0,11 \pm 0,01}$ & $\overline{99,5 \pm 2,99}$ & $1,7 \pm 0,05$ & $212,4 \pm 6,37$ & $\overline{2,4 \pm 0,07}$ \\
\hline \multirow{2}{*}{1000} & $\underline{5,2 \pm 0,16}$ & $\underline{0,09 \pm 0,03}$ & $\underline{167,6 \pm 5,02}$ & $\underline{46,2 \pm 1,39}$ & $262,6 \pm 7,88$ & $9,1 \pm 0,27$ \\
\hline & $\overline{2,9 \pm 0,09}$ & $\overline{0,08 \pm 0,01}$ & $\overline{66,3 \pm 1,90}$ & $\overline{1,6 \pm 0,05}$ & $\overline{191,4 \pm 5,74}$ & $\overline{1,6 \pm 0,05}$ \\
\hline \multirow{2}{*}{1500} & $\underline{5,0 \pm 0,15}$ & $\underline{0,10 \pm 0,02}$ & $\underline{158,9 \pm 4,77}$ & $\underline{22,5 \pm 0,68}$ & $255,7 \pm 7,67$ & $\underline{10,1 \pm 0,30}$ \\
\hline & $\overline{1,5 \pm 0,05}$ & $\overline{0,07 \pm 0,01}$ & $\overline{58,7 \pm 1,76}$ & $10,5 \pm 0,32$ & $115,8 \pm 3,47$ & $0,81 \pm 0,02$ \\
\hline \multirow{2}{*}{2000} & $\underline{5,2 \pm 0,16}$ & $\underline{0,08 \pm 0,03}$ & $\underline{124,4 \pm 3,73}$ & $20,0 \pm 0,60$ & $\underline{189,8 \pm 5,69}$ & $9,6 \pm 0,29$ \\
\hline & & $\overline{0,06 \pm 0,01}$ & $\overline{49,7 \pm 1,40}$ & $\overline{8,1 \pm 0,24}$ & $95,7 \pm 2,87$ & $0,75 \pm 0,02$ \\
\hline \multirow{2}{*}{2500} & $4,2 \pm 0,13$ & $\underline{0,09 \pm 0,01}$ & $102,7 \pm 3,08$ & $41,3 \pm 1,24$ & $195,7 \pm 5,87$ & $15,3 \pm 0,46$ \\
\hline & $\overline{0,8 \pm 0,02}$ & $\overline{0,08 \pm 0,01}$ & $\overline{56,7 \pm 1,70}$ & $\overline{0,8 \pm 0,02}$ & $96,7 \pm 2,90$ & $\overline{0,58 \pm 0,01}$ \\
\hline \multirow{2}{*}{3000} & $\underline{3,8 \pm 0,11}$ & $\underline{0,03 \pm 0,01}$ & $\underline{99,6 \pm 2,99}$ & $\underline{15,3 \pm 0,46}$ & $\underline{184,4 \pm 5,53}$ & $\underline{4,5 \pm 0,14}$ \\
\hline & $\overline{0,6 \pm 0,02}$ & $\overline{0,02 \pm 0,01}$ & $33,9 \pm 1,02$ & $1,5 \pm 0,05$ & $69,7 \pm 2,09$ & $\overline{0,49 \pm 0,01}$ \\
\hline \multirow{2}{*}{ Фон } & $\underline{5,36 \pm 0,16}$ & $\underline{0,06 \pm 0,01}$ & $\underline{34,9 \pm 1,05}$ & $19,8 \pm 0,59$ & $177,6 \pm 5,33$ & $\underline{10,7 \pm 0,32}$ \\
\hline & $0,12 \pm 0,04$ & $0,02 \pm 0,01$ & $16,4 \pm 0,49$ & $0,9 \pm 0,03$ & $36,1 \pm 1,08$ & $0,33 \pm 0,01$ \\
\hline
\end{tabular}

Примечания: $\mathrm{n}$ - количество образцов; $\bar{x}$ - среднее арифметическое; $s_{\bar{x}}$ - ошибка среднего арифметического

\section{Свинец}

Металл является обязательным компонентом ПНГ факельных установок, в связи с этим на расстоянии 50 и 100 м отмечается превышение валового содержания $\mathrm{Pb}$ относительно фона в 2 раза и в 0,5 раз на расстоянии 200 и 500 м (табл. 1). Превышение 
Девятова Т.А., Горбунова Н.С., Горбунова Ю.С., Гафар Х.Г. Распределение тяжелых металлов и бенз(а)пирена в нефтезагрязненных почвах города Кайяра (Ирак)

относительно фонового участка подвижных соединений Рb составляет от 5 до 24 раз и отмечается во всех образцах. Важным является то, что по сравнению с фоновым участком, где процент подвижности не превышает 2,24\%, при загрязнении сильно возрастает подвижность металла, которая достигает 55,8\% (табл. 2).

\section{Кадмий}

Валовое содержание металла в почвах на различном расстоянии от источника загрязнения постепенно уменьшается от 0,79 мг/кг (расстояние 1 м) до 0,03 мг/кг (на расстоянии 3000 м). Полученные данные превышают фоновые концентрации до расстояния в 3000 м (табл. 1). Превышение составляет от 1,5-3 раза при удалении от 200 м и более, при непосредственной близости к источнику загрязнения превышение составляет 13 раз. Что касается подвижных соединений, то следует отметить превышение относительно фона в 15 раз при непосредственной близости от источника загрязнения. Отмечается также постепенное снижение концентрации металла от источника загрязнения к периферии. Согласно литературным данным наибольшей миграционной способностью, как в загрязненных почвах [13], так и в фоновых обладает Cd. Согласно полученным данным (табл. 2), подвижность Сd достигает 91,7 \%.

\section{Никель}

Металл является канцерогенным элементом. Полученные данные по валовому содержанию $\mathrm{Ni}$ и его подвижным соединениям превышают его фоновое количество в 2-6 раз (табл. 1). Особую опасность представляет высокая подвижность элемента 34,0-65,3\% (табл. 2) в том числе и на фоновом участке.

\section{Цинк, марганец, медь}

Отмечается тенденция к накоплению валового содержания $\mathrm{Zn}, \mathrm{Mn}$ и $\mathrm{Cu}$, поскольку зафиксировано некоторое увеличение количества элементов относительно фонового участка (табл. 1). Превышение валового содержания $\mathrm{Zn}, \mathrm{Mn}$ и $\mathrm{Cu}$ относительно фона составляет 1,5-2 раза. $\mathrm{Zn}, \mathrm{Mn}$ и $\mathrm{Cu}$ не являются канцерогенными элементами и сильными загрязнителями, но их подвижные соединения превышают в 2-9 раз относительно фонового участка. Следует подчеркнуть высокую подвижность Mn (табл. 2), которая достигает 74,2\%. Что касается $\mathrm{Zn}$ и $\mathrm{Cu}$, то данные металлы достаточно прочно удерживаются карбонатами почвенного раствора, их профильная миграция затруднена. Учитывая обедненность следовыми химическими элементами почвообразующих пород и 
Девятова Т.А., Горбунова Н.С., Горбунова Ю.С., Гафар Х.Г. Распределение тяжелых металлов и бенз(а)пирена в нефтезагрязненных почвах города Кайяра (Ирак)

кор выветривания, растения исследуемой территории могут испытывать даже некоторый недостаток этих элементов.

Таблица 2. Процент подвижности исследуемых ТМ (мг/кг) в верхнем 0-20 см слое на различном расстоянии от источника нефтяного загрязнения

\begin{tabular}{|c|c|c|c|c|c|c|}
\hline \multirow{2}{*}{$\begin{array}{c}\text { Расстояние } \\
\text { от источника } \\
\begin{array}{c}\text { 3агрязнения, } \\
\text { м }\end{array}\end{array}$} & $\mathrm{Pb}$ & $\mathrm{Cd}$ & $\mathrm{Ni}$ & $\mathrm{Zn}$ & $\mathrm{Mn}$ & $\mathrm{Cu}$ \\
\cline { 2 - 7 } & & & & & & \\
\hline 1 & 15,1 & 38,0 & 53,1 & 32,1 & 56,6 & 18,4 \\
\hline 50 & 7,14 & 75,0 & 65,3 & 6,42 & 62,8 & 14,9 \\
\hline 100 & 13,8 & 72,0 & 42,2 & 15,6 & 73,8 & 7,26 \\
\hline 200 & 14,4 & 83,3 & 47,0 & 3,37 & 70,8 & 7,33 \\
\hline 500 & 16,1 & 91,7 & 52,5 & 4,58 & 74,2 & 12,9 \\
\hline 1000 & 55,8 & 88,9 & 39,6 & 3,46 & 72,9 & 17,6 \\
\hline 1500 & 30,0 & 70,0 & 36,9 & 46,7 & 45,3 & 8,02 \\
\hline 2000 & 19,2 & 75,0 & 39,9 & 40,5 & 50,4 & 7,81 \\
\hline 2500 & 19,0 & 88,9 & 55,2 & 1,94 & 49,4 & 3,79 \\
\hline 3000 & 15,8 & 66,7 & 34,0 & 9,80 & 37,8 & 10,9 \\
\hline Фон & 2,24 & 33,3 & 46,9 & 4,55 & 20,3 & 3,08 \\
\hline
\end{tabular}

\section{Нефтепродукты и бенз(а)пирен}

Фоновое содержание бенз(а)пирена в большинстве минеральных почв колеблется в пределах 0,1-5 мкг/кг [14]. Согласно полученным данным, количество без(а)пирена в фоновых почвах составляет 0,005 мг/кг. Такое низкое содержание связанно с легким гранулометрическим составом и незначительным содержанием органического вещества. На территории исследования, в зоне влияния нефтяных выбросов, количество бенз(а)пирена не превышает 0,96 мг/кг. При удалении от источника разлива отмечается постепенное снижение загрязнителя (рис. 4).

Несмотря на то, что разливы нефти в районе исследования отмечаются постоянно, фиксации бенз(а)пирена в почве не происходит. Содержание нефтепродуктов в районе влияния нефтяных разливов высокое. Максимальная концентрация сосредоточена на расстоянии 200 м от источника (рис. 5) и составляет 20340 мг/кг, что соответствует очень высокому уровню загрязнения нефтепродуктами. Допустимый уровень загрязнения (< 1000 мг/кг) характерен лишь для фонового участка и для почвы на расстоянии 3000 м от источника загрязнения. 
Девятова Т.А., Горбунова Н.С., Горбунова Ю.С., Гафар Х.Г. Распределение тяжелых металлов и бенз(а)пирена в нефтезагрязненных почвах города Кайяра (Ирак)

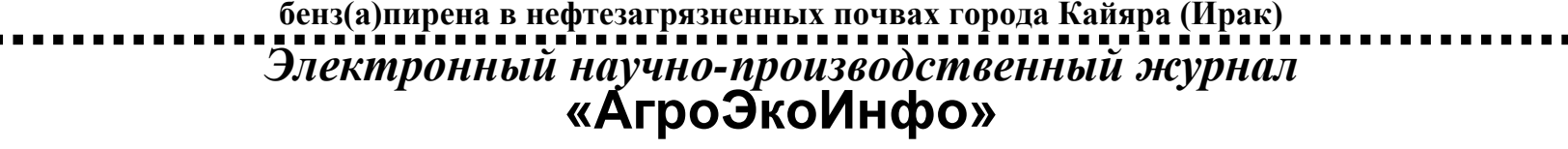

ニニニニニニニニニニニニニニニニニニニニニニニニニニニニニニニニニニニニニニニニニニニニニニニニ

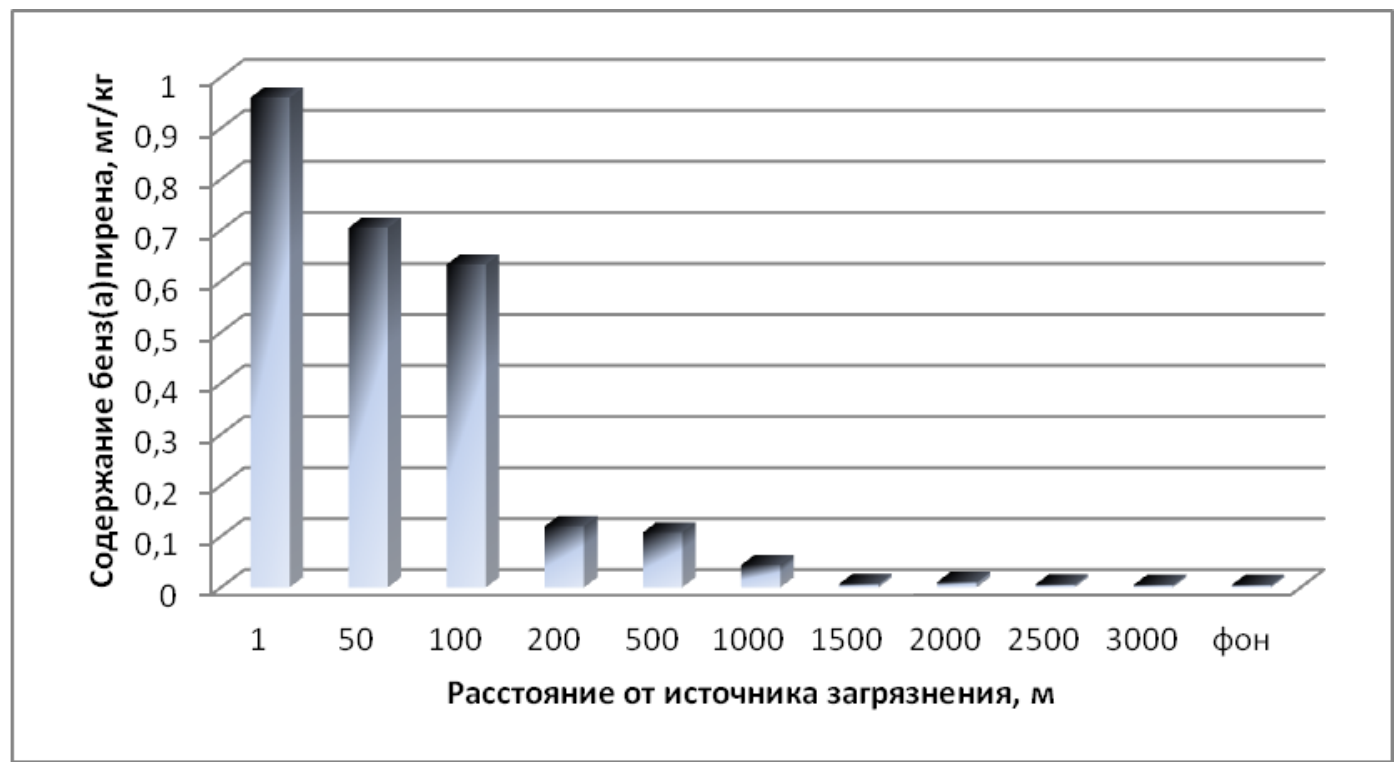

Рис. 4. Содержание бенз(а)пирена (мг/кг), в зависимости от источника нефтяного загрязнения

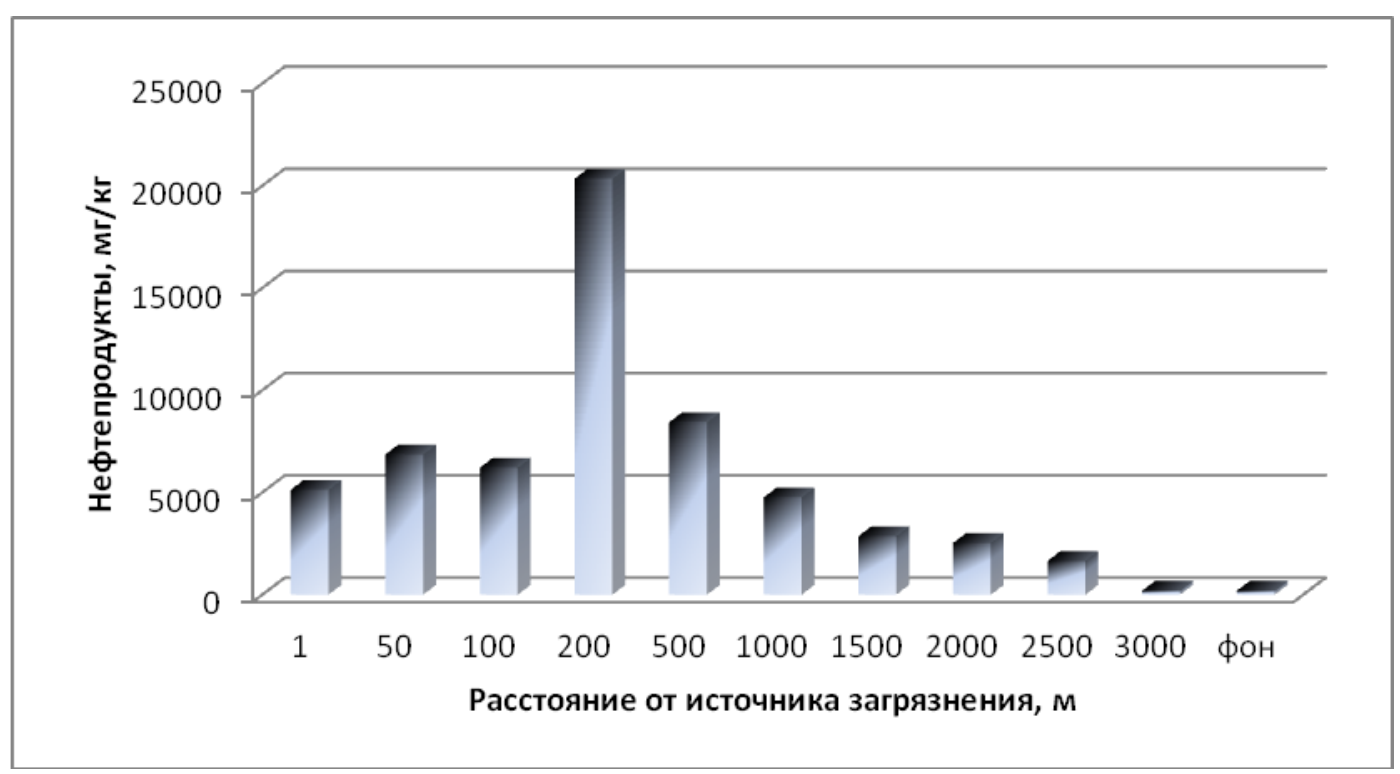

Рис. 5. Накопление нефтепродуктов (мг/кг), в зависимости от источника загрязнения

Исследуемые сероземы обладают низкими буферными свойствами, поскольку содержат незначительное количество гумуса и легкий гранулометрический состав. Поэтому существует вероятность не только накопления нефтепродуктов на поверхности почв, но и их интенсивная миграция в сопредельные среды. 
Девятова Т.А., Горбунова Н.С., Горбунова Ю.С., Гафар Х.Г. Распределение тяжелых металлов и бенз(а)пирена в нефтезагрязненных почвах города Кайяра (Ирак)

Ветровая эрозия, очень часто переходящая в пыльные бури в районе исследования может приводить к образованию новых очагов загрязнения ТМ, нефтепродуктами и бенз(а)пиреном.

\section{Заключение}

Изучаемая территория регулярно подвергается нефтяным разливам. Это связанно не только с аварийными ситуациями. В районе исследования происходит постоянное подтягивание нефтяных вод через тектонические трещины. Поднимаясь на поверхность воды производят специфическое засоление почвенного покрова. Поэтому почвы района исследования можно отнести к битуминозным хемоземам. Фоновые участки образованы полупустынными сероземами облегченного гранулометрического состава. Реакция почвенного раствора щелочная, она обусловлена как наличием известковых (карбонатных) кор выветривания, высокой минерализацией грунтовых вод, так и эволюцией ландшафта, которая направлена в сторону иссушения и соленакопления.

Закономерное распределение ТМ в пространстве (максимальное содержание около факельных установок сжигания ПНГ с постепенным уменьшением содержания по мере удаления от источника загрязнения) характерно только для $\mathrm{Cd}$ и частично для $\mathrm{Pb} . \mathrm{B}$ пространственном распределении остальных ТM данная закономерность не прослеживается. Описанному явлению способствуют интенсивные пыльные бури и ежедневная ветровая эрозия. Для всех исследуемых элементов характерно превышение их валового содержания и подвижных элементов относительно фона.

Особое внимание обращает на себя повышенная подвижность ТM, особенно $\mathrm{Cd}$, которая достигает 91,7\%. Несмотря на то, что карбонаты способны выступать геохимическим барьером на пути миграции исследуемых элементов, в данных почвенноклиматических условиях такой закономерности не отмечается. Повышенная подвижность ТМ может привести к их интенсивной миграции, к поступлению в растительные и животные организмы. Низкая буферная способность исследуемых пустынных сероземов не способна фиксировать вредные ингредиенты, что способно привести к тяжелым экологическим последствиям. Повсеместное развитие интенсивной ветровой эрозии почв на загрязненной территории может вызвать образование новых очагов загрязнения в 
Девятова Т.А., Горбунова Н.С., Горбунова Ю.С., Гафар Х.Г. Распределение тяжелых металлов и бенз(а)пирена в нефтезагрязненных почвах города Кайяра (Ирак)

местах аккумуляции сдутой почвы. Необходимо разработать комплекс мер, направленных на устранение загрязнения. Планирование должно учитывать местные особенности.

\section{Список использованных источников}

1. Cocartă D.M., Stoian M.A., Karademir A. Crude oil contaminated sites: evaluation by using risk assessment approach // Sustainability. - 2017. - № 9. - P. 1365-1380.

2. Sushkova S., Minkina T., Dudnikova T., Barbashev A., Mazarji M., Chernikova N., Lobzenko I., Deryabkina I., Kizilkaya R. Influence of carbon-containing and mineral sorbents on the toxicity of soil contaminated with benzo[a]pyrene during phytotesting // Environmental Geochemistry and Health. - 2021. - P. 1-15.

3. Сазонова О.В., Рязанова Т.К., Тупикова Д.С., Судакова Т.В., Торопова Н.М., Вистяк Л.Н., Соколова И.В., Сучков В.В. Влияние предприятий нефтехимического комплекса на состояние почвенного покрова на территории Самарской области // Почвоведение. - 2018. - № 10 (приложение). - C. S10-S22.

4. Mazarji M., Minkina T.M., Sushkova S.N., Mandzhieva S.S., Barbashev A.V., Bidhendi G.N., Bhatnagar A. Effect of nanomaterials on remediation of polycyclic aromatic hydrocarbons-contaminated soils: a review // Journal of environmental management. - 2021. - V. 284. - P. 112023.

5. Ковалева Е.И., Яковлева А.С., Николаенко (Кегиян) М.Г., Макаров А.О., Макаров А.А. Экологическая оценка нефтезагрязненных почв с использованием энхитреид (о. Сахалин) // Почвоведение. - 2017. - № 3. - С. 360-369.

6. Методика расчета выбросов вредных веществ в атмосферу при сжигании попутного нефтяного газа на факельных установках. Утв. приказом Госкомэкологии России № 199 от 08.04.1998 г. СПб., НИИ «Атмосфера». 1997. - 26 с.

7. Липатов Д.Н., Щеглов А.И., Манахов Д.В., Карпухин М.М., Завгородняя Ю.А., Цветнова О.Б. Распределение тяжелых металлов и бенз(а)пирена в торфяных олиготрофных почвах и торфяно-глееземах на северо-востоке о. Сахалин // Почвоведение. - 2018. - №5. - С. 551-562.

8. Солнцева Н.П. Добыча нефти и геохимия природных ландшафтов. - М.: Изд-во МГУ, 1998. - 376 с.

9. Перельман А.И., Касимов Н.С. Геохимия ландшафта. - М.: Астрея-2000, 1999. $768 \mathrm{c}$.

10. Добровольский В.В. Геохимия почв и ландшафтов. - М.: Научный мир, 2009. T. $2 .-752$ c.

11. Ковда В.А. Проблемы опустынивания и засоления почв аридных регионов мира. - М.: Наука, 2008. - 415 с. 
Девятова Т.А., Горбунова Н.С., Горбунова Ю.С., Гафар Х.Г. Распределение тяжелых металлов и бенз(а)пирена в нефтезагрязненных почвах города Кайяра (Ирак)

12. Семенков И.Н., Королева Т.В. Международные системы нормирования содержания химических элементов в почвах: принципы и методы (обзор) // Почвоведение. - 2019. - №10. - C. 1259-1268.

13. Фрид А.С., Борисочкина Т.И. Миграционная подвижность тяжелых металлов в сильнозагрязненных почвах в окресностях комбината «Североникель» (Мурманская область) // Почвоведение. - 2020. - № 9. - С. 1144-1154.

14. Сушкова С.Н., Минкина Т.М, Манджиева С.С., Тюрина И.Г., Васильева Г.К., Кизилкая Р. Мониторинг содержания бенз(а)пирена в почвах под влиянием многолетнего техногенного загрязнения // Почвоведение. - 2017. - № 1. - С. 105-116.

\section{Цитирование:}

Девятова Т.А., Горбунова Н.С., Горбунова Ю.С., Гафар Х.Г. Распределение тяжелых металлов и бенз(а)пирена в нефтезагрязненных почвах города Кайяра (Ирак) [Электрон. ресурс] // АгроЭкоИнфо: Электронный научно-производственный журнал. 2022. - №1. - Режим доступа: http://agroecoinfo.ru/STATYI/2022/1/st_116.pdf.

DOI: https://doi.org/10.51419/202121116. 